\title{
PERSEPSI GENERASI MILENIAL TERHADAP TRADISI GREBEG BESAR DI KABUPATEN DEMAK
}

\author{
Eka Erni Nurrokhmah*1, Dian Fatimatus Salwa ${ }^{2}$, Khikmatul Laili Desiani ${ }^{3}$, Tia Rosalita ${ }^{4}$ \\ Pesantren Riset Al-Muhtada, Semarang, Indonesia \\ e-mail: ekaaerni97@gmail.com
}

\begin{abstract}
Abstrak
Provinsi Jawa Tengah memiliki sebuah daerah yang menjadi cikal bakal Islam di Jawa, daerah tersebut yakni Kota Demak. Terdapat banyak sekali peninggalan berupa catatan dan bukti sejarah, hal tersebut tergambar jelas dengan adanya masjid Agung Demak dan Makam Sunan Kalijaga. Selain itu Demak juga memiliki tradisi budaya serta peninggalan yang cukup beragam dan unik. Salah satu tradisi yang unik dan masih berlangsung adalah tradisi Grebeg Besar. Warga masyarakat Demak biasa mengadakan tradisi Grebeg Besar Demak setiap tanggal 10 Dzulhijjah sebagai sarana menyambut hari lebaran haji atau qurban. Tradisi Grebeg Besar Demak tersebut berupa rangkaian upacara tradisional yang nilainya kental dengan ritual keagamaan Islam. Tujuan pelaksanaan tradisi Grebeg Besar Demak selain sebagai wujud pelestarian tradisi budaya dan syiar Islam, juga sebagai peningkatan sumber Pendapatan Asli Daerah (PAD). Eksistensi grebeg besar tidak dapat diragukan lagi, seтиа peтuda-pemudi berbondong-bondong untuk mendatanginya. Sehingga dari latar belakang tersebut, peneliti ingin mengetahui lebih dalam mengenai persepsi generasi milenial terhadap pelaksanaan grebeg besar, mengingat generasi milenial adalah generasi emas penerus bangsa yang harus berpartisipasi dalam melestarikan budaya tradisi masyarakat yang ada agar tidak luntur. Hasil dari penelitian menunjukkan bahwa persepsi generasi milenial Demak terhadap tradisi Grebeg Besar Demak antara lain sebagai media pelestarian budaya, sarana religi, hiburan, dan meningkatkan pendapatan ekonomi.
\end{abstract}

Kata kunci-grebeg besar, milenial, persepsi

\section{PENDAHULUAN}

Kabupaten Demak adalah salah satu kota yang ada di Provinsi Jawa Tengah. Kota ini menjadi awal mula agama Islam di Jawa yang meninggalkan banyak catatan serta bukti sejarah seperti makam Sunan Kalijaga dan Masjid Agung Demak. Tradisi budaya serta peninggalan yang ada di Demak cukup beragam dan unik. Salah satu tradisi yang unik dan masih berlangsung adalah tradisi Grebeg Besar. Grebeg adalah upacara ritual yang digunakan sebagai sarana ucapan syukur kepada Allah atas karunia yang telah diberikan sekaligus sebagai permohonan kepada-Nya supaya senantiasa diberikan kesejahteraan dan keselamatan ${ }^{1}$. Prosesi Grebeg Besar Demak diadakan satu tahun sekali saat hari raya Idul Adha atau tanggal 10 Dzulhijjah. Tradisi ini dimeriahkan oleh kirab

\footnotetext{
${ }^{1}$ Wahyu Illaihi, "Komunikasi Dakwah,” Remaja Rosdakarya, 2010, 122.
}

Al Qalam: Jurnal Ilmiah Keagamaan dan Kemasyarakatan Vol. 16, No. 1

Januari - Juni 2022 
budaya yang dimulai dari Pendopo Kabupaten Demak sampai Makam Sunan Kalijaga yang letaknya berada di Desa Kadilangu².

Tradisi Grebeg Besar berkaitan erat dengan sejarah perjuangan Wali Songo dalam memperjuangkan penyebaran agama Islam di abad ke-15. Pada masa itu, Demak sebagai pusat (Kesultanan Bintoro) di Pulau Jawa. Sultan Fattah dan Sunan Kalijaga merupakan seorang tokoh yang memiliki pengaruh sangat besar dalam sejarah Kabupaten Demak. Pada masa kejayaan pemerintahan Sultan Fattah dengan dewan penasihat spiritualnya yaitu Sunan Kalijaga, beliau menyelenggarakan Grebeg. Acara Grebeg tersebut digelar sebagai media dakwah. Adapun acara Grebeg yang digelar yaitu Grebeg Besar, Grebeg Dal, Grebeg Maulid, serta Grebeg Syawal. Satusatunya budaya Grebeg yang sampai sekarang tetap eksis dan dilestarikan di Kabupaten Demak yakni tradisi Grebeg Besar ${ }^{3}$.

Pada saat ini tujuan pelaksanaan tradisi Grebeg Besar Demak selain sebagai wujud pelestarian tradisi budaya dan syiar Islam, juga sebagai peningkatan sumber Pendapatan Asli Daerah (PAD). Secara alternatif, pelaksanaan tradisi Grebeg Besar Demak dijelaskan di Peraturan Daerah Kabupaten Demak Nomor 08 Tahun 2010 Bab 1 Pasal 1 tentang Retribusi Tempat Rekreasi dan Olah Raga yang menyatakan bahwa event budaya merupakan kegiatan yang memiliki tujuan untuk melestarikan dan memperingati sejarah atau budaya masyarakat. Selanjutnya pada Pasal 3 menjelaskan bahwa salah satu obyek retribusinya adalah event budaya, termasuk acara Grebeg Besar Demak tersebut.

Partisipan acara Tradisi Grebeg Besar ini biasanya adalah masyarakat dari berbagai daerah, didominasi oleh para remaja utamanya generasi milenial. Generasi milenial sendiri merupakan bentuk diferensiasi antara generasi pada tahun sekitar 90-an dengan generasi di zaman sekarang, generasi milenial berada pada rentang umur 15-30 tahun ${ }^{4}$. Kata milenial diciptakan oleh Willian Strauss dan Neil Howe tahun 1987, mereka menciptakannya ketika anak yang terlahir pada tahun 1982 masuk pendidikan prasekolah, ketika itu media menganggap sebagai golongan yang terhubung ke millenium baru saat lulus SMA pada tahun 2000. Sedangkan remaja milenial merupakan generasi remaja yang tumbuh dalam lingkungan serba digital yang mana lingkungan sekitarnya telah mengalami perkembangan teknologi dalam berbagai bidang. Sejak kecil para remaja tersebut telah akrab dengan kecanggihan teknologi, Hal tersebut sedikit banyak tentunya memberikan perbedaan antara generasi remaja milenial dengan generasi sebelumnya. Jika generasi

\footnotetext{
${ }^{2}$ Ani Aliatus Syarifah, "Peran Masjid Agung Demak Terhadap Tradisi Grebeg Besar Di Daerah Demak" 151, no. 2 (2018): 10-17.

3 Illaihi, "Komunikasi Dakwah."

${ }^{4}$ Saleha Astri Rahaningmas, Sri Wahyuni, and Muh Mahendra, "Penggunaan Bahasa Indonesia Di Kalangan Generasi Milenial,” 2019, https://doi.org/10.31227/osf.io/r6wku.
}

Al Qalam: Jurnal Ilmiah Keagamaan dan Kemasyarakatan Vol. 16, No. 1 Januari - Juni 2022 
pada masa lampau banyak menghabiskan waktu remajanya dengan bergaul bersama teman sebaya, generasi milenial umumnya lebih banyak menghabiskan waktu dengan gawai yang dimilikinya.

Pengertian persepsi berdasarkan teori konstruksi sosial oleh Peter L. Berger dan Thomas Luckman (1966: 56) menyatakan jika persepsi mengandung pemaknaan bahwa perspektif dalam memandang dunia antara satu orang dengan orang lain selalu memiliki kesamaan. Namun, setiap pribadi juga memiliki perbedaan perspektif dalam memandang kehidupan sehari-hari yang sifatnya absolute. Setiap orang memiliki perspektif yang mungkin tidak hanya berbeda, namun bahkan bertentangan.

Maka dengan adanya perbedaan generasi tersebut peneliti ingin mengetahui bagaimana sejarah dan filosofi dari tradisi Grebeg Besar Demak dan juga bagaimana persepsi generasi milenial terhadap tradisi Grebeg Besar Demak sehingga diharapkan pada penelitian diperoleh tujuan yakni untuk mengetahui sejarah dan filosofi dari tradisi Grebeg Besar Demak dan untuk mengetahui persepsi generasi milenial terhadap tradisi Grebeg Besar Demak.

Berdasarkan penelitian yang dilakukan oleh Iwan Effendy (2014) menyebutkan bahwa fungsi Grebeg Besar mengalami perubahan menjadi pasar malam yang dijadikan pemerintah sebagai alat dalam menambah pemasukan daerah sekaligus sebagai tempat bertemu masyarakat untuk berinteraksi satu sama lain serta menjadi tempat masyarakat dalam menambah penghasilan mereka melalui cara berjualan atau menyediakan jasa ${ }^{5}$. Dengan demikian, penelitian ini akan melanjutkan, menambah, ataupun menyempurnakan penelitian terdahulu dan sekaligus untuk menghindari adanya duplikasi penelitian dari sudut pandang persepsi generasi milenial.

\section{KAJIAN TEORI}

\section{Teori Persepsi}

Deddy Mulyana menyatakan bahwa terdapat tiga unsur yang berpengaruh besar terhadap maknamakna dalam persepsi seseorang, yakni meliputi sistem-sistem kepercayaan, nilai, dan sikap; pandangan dunia; serta organisasi sosial ${ }^{6}$.

Berdasarkan teori konstruksi sosial, persepsi antara satu orang dengan lainnya selalu sama dalam memandang dunia bersama. Begitupun dengan persepsi Grebeg Besar Demak, antara seseorang dengan yang lainnya akan selalu memiliki kecenderungan yang sama dalam aspek tertentu. Akan tetapi, dalam waktu yang bersamaan pula akan terdapat perbedaan, sebagaimana persepsi itu sendiri dipengaruhi oleh bermacam faktor yang dapat mengakibatkan hasil persepsi antara seseorang

\footnotetext{
${ }^{5}$ Iwan Effendy, "Dinamika Grebeg Besar Demak ( Tinjauan Sejarah Dan Tradisi )," Journal of Indonesian History 3, no. 1 (2014): 19-26.

${ }^{6}$ Istivani Elvia Rini, "Makna Tradisi Grebeg Suro Dalam Melestarikan Budaya Bangsa Bagi Masyarakat (Studi Kasus Masyarakat Kelurahan Baluwarti Kecamatan Pasar Kliwon Surakarta)," UNIVERSITAS SEBELAS MARET (UNIVERSITAS SEBELAS MARET SURAKARTA, 2012), https://digilib.uns.ac.id/dokumen/detail/25392.
}

Al Qalam: Jurnal Ilmiah Keagamaan dan Kemasyarakatan Vol. 16, No. 1 Januari - Juni 2022 
dengan yang lainnya tidak sama, misalkan karena perbedaan lingkup sosial, pendidikan, pengalaman, pandangan dunia, dan lain sebagainya ${ }^{7}$.

\section{Teori Kebudayaan}

Menurut Kuntowijoyo, kebudayaan merupakan kompleks yang terdiri atas kepercayaan, pengetahuan, moral, kesenian, adat-istiadat, hukum, kemampuan-kemampuan, serta kebiasaankebiasaan yang didapatkan oleh manusia sebagai bagian dari masyarakat. Terdapat dua konsep kebudayaan, yakni kebudayaan sebagai sistem adaptif dan kebudayaan sebagai sistem ideasional. Kebudayaan sebagai sistem adaptif merupakan kebudayaan yang hubungannya antara manusia dengan alam dimana terdapat penyesuaian atau adaptasi terhadap seleksi alami di dalamnya. Sedangkan kebudayaan sebagai sistem ideasional, yaitu budaya memiliki peran sebagai ide atau gagasan ${ }^{8}$.

Teori kebudayaan merupakan salah satu bentuk usaha secara konseptual dalam memahami bagaimana manusia menggunakan kebudayaan untuk mempertahankan kehidupannya melalui penggarapan lingkungan alam, melangsungkan kehidupannya dalam kelompok, dan memelihara keseimbangannya dengan dunia supranatural ${ }^{9}$.

Berdasarkan konsep kebudayaan yang menempatkan kebudayaan sebagai sistem adaptif, tidak menutup kemungkinan bahwa Grebeg Besar Demak juga termasuk diantaranya sebagai kebudayaan yang mengalami adaptasi dengan perkembangan zaman. Perubahan alam, zaman, hingga pola pikir manusia dapat memberikan kemungkinan bahwa Grebeg Besar Demak dapat mengalami pergeseran makna, nilai, atau bahkan tata cara dalam penyelenggaraannya.

\section{METODE PENELITIAN}

Metode yang digunakan dalam proses penelitian ini yakni menggunakan metode penelitian kualititatif dengan jenis penelitian yang digunakan yakni penelitian deskriptif. Penelitian ini berfokus pada bagaimana persepsi generasi milenial yang ada di Kabupaten Demak memaknai banyaknya nilai yang terkandung dalam tradisi Grebeg Besar Demak. Di samping itu, kami juga menggali informasi terkait sejarah dan filosofi tradisi Grebeg Besar Demak. Penelitian dilakukan di Dusun Tembiring, Desa Bintoro, Kecamatan Demak, Kabupaten Demak, Jawa Tengah pada tanggal 17 Maret 2021 dan 24 Maret 2021.

Sumber data primer penelitian ini diperoleh secara langsung dari pihak Dinas Pariwisata melalui wawancara dengan Bapak Sutomo selaku Lurah Tamtomo yang berperan langsung dalam

\footnotetext{
${ }^{7}$ Indra Taufik, "Persepsi Masyarakat Terhadap Pemulung Di Pemukiman TPA Kelurahan Bukit Pinang Kecamatan Samarinda Ulu," Journal Sosiologi 1, no. 4 (2015): 85-95.

${ }^{8}$ Ida Zahara Adibah, "Penyelidikan Sejarah Tentang Masyarakat Dan Budaya," Jurnal Madaniyah 9, no. 1 (2019): 143-62.

${ }^{9}$ Dance Wamafma, "Survey Terhadap Budaya Jepang Pada," Penelitian mandiri (Bandung, 2012), http://repository.maranatha.edu/3235/1/Budaya Dalam Bisnis Jepang.pdf.
}

Al Qalam: Jurnal Ilmiah Keagamaan dan Kemasyarakatan Vol. 16, No. 1 Januari - Juni 2022 
tradisi Grebeg Besar Demak ini sebagai tokoh pada Kasultanan Bintoro Demak yang mendapat amanah dari Bupati Demak untuk membawa Minyak Jamas untuk menggali informasi terkait sejarah dan filosofi Grebeg Besar Demak. Selain menggunakan sumber data primer, penelitian ini juga menggunakan sumber data sekunder yang dilakukan melalui studi literatur, baik dari jurnal yang tersedia maupun dari buku yang didapat dari Dinas Kebudayaan Kabupaten Demak. Selain itu teknik observasi dan dokumentasi juga dipilih sebagai teknik yang digunakan dalam penelitian ini yang mana dilakukan di Museum Masjid Agung Demak.

Sumber data primer yang diperoleh tidak hanya melalui wawancara tetapi juga melalui media google form yang disebarkan secara online kepada para millenial Demak. Media google form ini digunakan untuk mengumpulkan data terkait persepsi generasi millenial terhadap Grebeg Besar Demak. Berdasarkan data yang telah diperoleh selanjutnya dilakukan pengecekan keabsahan data menggunakan teknik triangulasi. Teknik triangulasi merupakan pengecekan data yang dilakukan dengan cara pemeriksaan ulang, meliputi triangulasi sumber, triangulasi metode, dan triangulasi waktu $^{10}$. Data reduction, data display, dan conclusion drawing/verification merupakan beberapa langkah yang dilakukan peneliti untuk menganalisis data ${ }^{11}$.

\section{HASIL DAN PEMBAHASAN}

\section{Sejarah dan Filosofi Tradisi Grebeg Besar Demak}

Acara Grebeg Besar Demak merupakan suatu tradisi tahunan yang diperingati oleh masyarakat kabupaten Demak setiap bulan Dzulhijjah. Disebut sebagai Grebeg 'Besar' sebab bulan Dzulhijjah disebut sebagai 'sasi besar' dalam penamaan bulan jawa, puncak dari Grebeg Besar Demak itu sendiri dilaksanakan tepatnya pada hari raya Idul Adha, atau orang-orang Jawa juga menyebutnya sebagai 'bodo besar'. Kata grebeg sendiri dapat diartikan sebagai digiring, dikumpulkan, dan dikepung, atau bisa juga berarti dikumpulkan dalam suatu tempat untuk kepentingan khusus. Dengan demikian, Grebeg Besar merupakan berkumpulnya masyarakat muslim pada bulan Dzulhijjah (Bulan Besar) yang dilaksanakan setiap satu tahun sekali di Masjid Agung Demak untuk kepentingan Islamiyah ${ }^{12}$.

Menurut Bapak Sutomo selaku Lurah Tamtomo, Grebeg Besar Demak merupakan sebuah tradisi yang telah turun temurun di daerah Demak sejak zaman para wali dulu, dimulai pada abad XV ketika Demak menjadi pusat (Kasultanan Bintoro) di pulau Jawa. Grebeg besar pada mulanya menjadi sarana bagi para wali khususnya Sunan Kalijaga dalam menyebarkan ajaran Islam. Melalui

\footnotetext{
${ }^{10}$ Halleludin dan Hengki Wijaya, Analisis Data Kualitatif: Sebuah Tinjauan Teori \& Praktik (Makassar: Sekolah Tinggi Theologia Jaffray, 2019):135-136.

11 Sugiyono, Metode Penelitian Kuantitatif, Kualitatif, Dan R\&D. (Bandung: Penerbit Alfabeta, 2013): 245-247.

${ }^{12}$ Effendy, "Dinamika Grebeg Besar Demak ( Tinjauan Sejarah Dan Tradisi ).”
}

Al Qalam: Jurnal Ilmiah Keagamaan dan Kemasyarakatan Vol. 16, No. 1

Januari - Juni 2022 
kegiatan ini, para wali dapat menjadi lebih dekat kepada masyarakat sehingga mereka lebih mudah untuk berdakwah kepada masyarakat Demak. Disamping itu, Grebeg Besar ini juga berperan sebagai pesta rakyat, sebagai hiburan agar masyarakat tidak jenuh terlebih dalam menerima dakwah dan ajaran Islam.

Klimaks atau puncak dari acara Grebeg Besar itu sendiri adalah ketika iring-iringan minyak jamas yang dibawa oleh seorang lurah Tamtomo, dulunya ada wasiat sunan Kalijaga yang berbunyi "agemanku besok yen dikeparengake selehno neng duwur pituronku kejaba kuwi sak wus e aku kukut agemanku jamas". Wasiat tersebut kurang lebih memiliki arti bahwasannya Sunan Kalijaga berwasiat kepada para ahli warisnya agar menjamas ageman (pusaka) beliau dan meletakkannya di atas makam (pusara) beliau ketika beliau telah wafat. Itulah sebabnya kegiatan penjamasan menjadi salah satu bagian inti yang paling sakral dari rangkaian pelaksaan tradisi Grebeg Besar Demak.

Ageman yang dimaksud diatas ialah dua buah pusaka, yang pertama adalah potang ontokusumo yang dikiaskan sebagai agama islam (dua kalimat syahadat) sedangkan yang kedua yang kedua keris kiyai carubuk. Ketika Raden Said (Sunan Kalijaga) berdakwah, keris tersebut selalu dibawa sebagai piandel kekuatan. Dalam kegiatan penjamasan, kedua ageman tersebut dijamas dengan minyak jamas yang terbuat dari terbuat dari campuran tujuh kembang setaman dengan minyak kelapa muda hijau dan diramu oleh sembilan orang ibu-ibu yang tidak sedang mengalami menstruasi atau dalam keadaan suci. Jadi, minyak jamas ini hanya dimiliki oleh orangorang tertentu. Bagi beberapa masyarakat, kegiatan penjamasan kedua pusaka Sunan Kalijaga tersebut memiliki kekuatan gaib yang dipercaya membawa keberkahan tersendiri. Lurah Tamtomo yang berperan sebagai pembawa minyak jamas menuturkan bahwa setelah kegiatan penjamasan keris tersebut selesai banyak masyarakat yang berpartisipasi dalam acara Grebeg Besar tersebut berbondong-bondong kepadanya untuk sekedar bersalaman dan mencium tangan beliau. Beberapa bahkan mengaku bahwa setelah bersalaman dengan beliau dalam acara Grebeg Besar ada banyak keberuntungan atau hal-hal baik yang datang dalam hidupnya. Misal saja seorang pedagang yang turut menghadiri acara Grebeg Besar tersebut pernah bercerita bahwa saat di Demak dagangannya memang sepi namun beberapa hari kemudian ketika pindah ke lain tempat dagangannya menjadi laris manis. Meskipun begitu, Bapak Sutomo (Lurah Tamtomo) menuturkan bahwa beliau tidak tahu menahu masalah tersebut dan beliau menganggap bahwa hal tersebut kembali lagi pada keyakinan masing-masing individu.

Tradisi Grebeg Besar berpusat di Masjid Agung Demak, Makam Sunan Kalijaga, pendapa Kabupaten Demak, dan Tembiring Jogo Indah. Kegiatan pertama yang dilakukan dalam serangkaian acara Grebeg Besar adalah pisowanan ke bupati Demak yang diibaratkan sebagai raja Demak. Selanjutnya bupati dan para jajarannya berziarah ke makam Sultan Demak Bintoro. Kemudian acara peresmian pembukaan, dilanjutkan dengan prosesi iring-iringan tumpeng sembilan

Al Qalam: Jurnal Ilmiah Keagamaan dan Kemasyarakatan Vol. 16, No. 1 Januari - Juni 2022 
dari pendopo kabupaten ke Masjid Agung Demak. Pagi harinya (tanggal 10 Dzulhijjah) dilaksanakan kirab prajurit 40 yang mendampingi bupati Demak yang disimbolkan sebagai Raja Demak untuk membawa minyak jamas dan kembang setaman untuk dibawa ziarah ke makam sunan Kalijaga.

Pada serangkaian acara tradisi Grebeg Besar Demak terdapat Nari bedoyo tunggal jiwo, lagu Lir-ilir, dan setelah itu pimpinan prajurit 40 laporan kepada lurah Tamtomo. Selanjutnya Lurah Tamtomo melapor kepada Bupati Demak. Adapun tumpeng yang dibawa dari pendopo ke masjid agung itu tingkatannya berjumlah sembilan, ini melambangkan Walisongo yang berjumlah sembilan. Menurut masyarakat tumpeng tersebut akan membawa berkah jika dimakan.

Pelaksanaan grebeg besar Demak yang pertama kali dilakukan oleh para Wali ini akan terus dilestarikan secara turun temurun. Seiring perkembangan zaman, grebeg besar mengalami inovasi. Sebelum pelaksanaan puncak grebeg besar, lurah Tamtomo ziarah ke makam sunan Kalijaga sekaligus berdoa agar acara esok hari (puncak grebeg besar) dapat diberi kelancaran, keamanan, ketentraman, dan keraharjan.

\section{Persepsi Generasi Milenial terhadap Tradisi Grebeg Besar Demak}

Sebagai Media Pelestarian Budaya

Dikatakan sebagai media pelestarian budaya, sebab meskipun zaman sudah modern dan semakin berubah, tradisi Grebeg Besar Demak ini harus senantiasa dilestarikan dan dilaksanakan. Hal ini perlu dilakukan supaya anak zaman sekarang yang notabennya lekat dengan teknologi, tidak melupakan budayanya dan tahu akan asal usul serta sejarah Kabupaten Demak. Karena seperti yang kita ketahui Indonesia negara yang memiliki banyak budaya lebih khusus lagi Kota Demak yang mana terkenal dengan Kota Wali. Hal ini sepatutnya harus dilestarikan bukan ditinggalkan apalagi di lupakan. Selain sebagai media pelestarian budaya, tradisi Grebeg Besar Demak ini juga bisa menjadi media edukasi terkhusus bagi pelajar dan masyarakat pada umunya mengenai Kabupaten Demak yang mana terdapat banyak wali dan sebagai wilayah pusat penyebaran agama Islam di Pulau Jawa. Hal ini tersirat dalam rangkaian acara Grebeg Besar Demak.

Sebagai Sarana Religius

Dikutip dari website pariwisata.demakkab.go.id, tradisi Grebeg Besar di Kabupaten Demak tidak lepas dari sejarah perjuangan Wali Songo dalam upaya menyebarkan agama Islam pada abad ke XV di Demak sebagai pusat (Kasultanan Bintoro) di pulau Jawa dengan masterpieces-nya adalah Sultan Fattah dan Sunan Kalijaga sebagai tokoh besar yang berpengaruh dalam sejarah Kabupaten Demak $^{13}$. Ketika masa kejayaan pemerintahan Sultan Fattah dan Sunan Kalijaga sebagai penasehat

\footnotetext{
13 “Tradisi Grebeg Besar," Dinas Pariwisata kabupaten Demak, 2019, http://pariwisata.demakkab.go.id/?p=964 .
}

Al Qalam: Jurnal Ilmiah Keagamaan dan Kemasyarakatan Vol. 16, No. 1

Januari - Juni 2022 
spiritualnya, beliau menyelenggarakan Grebeg sebagai media dakwah diantaranya adalah Grebeg Maulid, Grebeg Dal, Grebeg Syawal, dan Grebeg Besar. Namun, yang hingga sekarang tetap dilestarikan adalah budaya Grebeg Besar setiap tanggal 10 Dzulhijjah (Idul Adha). Sementara Grebeg lainnya yang masih dilestarikan di Keraton Solo, Yogyakarta dan Cirebon. Namun sayang, dari 33 responden hanya satu responden yang menyebutkan Grebeg Besar Demak memiliki makna religius dan bersifat spriritual. "Tradisi grebeg besar Demak merupakan suatu tradisi yang diadakan satu tahun sekali. Semua rangkaian acara dalam tradisi tersebut memiliki sebuah makna yang sangat religius dan bersifat spiritual." (Adhita Febriana, IMADE). Selain dari sejarah adanya Grebeg Besar Demak, makna religius tersebut juga bisa terlihat dari rangkaian acara Grebeg Besar Demak yang mana pada prosesi iring- iringan tumpeng 9 dari pendopo Kabupaten Demak menuju serambi Masjid Agung dan dilanjutkan dengan pengajian umum. Artinya disamping pelestarian budaya dan hiburan prosesi tradisi Grebeg Besar Demak ini juga bisa menjadi media dakwah karena adanya pengajian umum.

Sebagai Hiburan

Selain sebagai media pelestarian budaya dan sarana religius, tradisi Grebeg Besar Demak ini juga bisa dijadikan sebagai sarana hiburan bagi masyarakat Kabupaten Demak dan menarik wisatawan untuk berkunjung ke Kabupaten Demak. "Saya setuju karena itu sebuah tradisi yang baik agar generasi muda tidak lupa terhadap tradisi selain itu, ada hiburan saat acara seperti itu yang sangat menghibur dan menarik bagi masyarakat sekitar." (Devi Vebriani, IMADE). Dalam hal ini tentu saja tentu saja tidak hanya sebagai hiburan semata, akan tetapi juga tetap memperhatikan sisi makna dan esensi utama dari tradisi itu sendiri.

Sebagai Peningkatan Pendapatan Ekonomi

Adanya kegiatan pasar malam juga mebuat meningkatnya ekonomi bagi para pedagang yang ada di Kabupaten Demak, karena pasar malam tersebut mendatangkan banyak orang dari berbagai daerah serta di hari $\mathrm{H}$ acara tradisi Grebeg Besar Demak juga membuat orang ramai-ramai datang untuk menyaksikan rangkaian acara tradisi Grebeg Besar Demak. Akibatnya para pedagang yang semula sepi ataupun biasa saja mengalami peningkatan penjualan sehingga pendapatan ekonomi pun meningkat, termasuk juga pada peningkatan sumber Pendapatan Asli Daerah (PAD).

\section{KESIMPULAN}

Pertama, tradisi Grebeg Besar disebut sebagai grebeg 'Besar' sebab bulan Dzulhijjah disebut sebagai 'sasi besar' dalam penamaan bulan jawa dan dilaksanakan pada hari raya idul Adha. Kata grebeg diartikan sebagai digiring, dikepung, di arak dan dikumpulkan atau dapat diartikan berkumpulnya orang di suatu tempat dalam rangka kepentingan yang khusus. Dengan demikian, Grebeg Besar merupakan berkumpulnya masyarakat yang beragama Islam pada bulan Dzulhijjah (Bulan Besar) di Masjid Agung Demak untuk kepentingan islamiyah. Grebeg Besar Demak 
merupakan sebuah tradisi turun temurun yang ada di daerah Demak sejak zaman para wali, dimulai sekitar pada abad XV ketika Demak dijadikan pusat (Kasultanan Bintoro) yang ada di pulau Jawa. Pada mulanya Grebeg Besar Demak menjadi sarana bagi para wali khususnya Sunan Kalijaga dalam proses menyebarkan ajaran islam. Melalui kegiatan ini, para wali dapat menjadi lebih dekat kepada masyarakat sehingga mereka lebih mudah untuk berdakwah kepada masyarakat Demak.

Kedua, persepsi generasi milenial yang ada di Kabupaten Demak terhadap tradisi Grebeg Besar Demak adalah sebagai media pelestarian budaya, sarana religi, sebagai hiburan, dan juga meningkatkan pendapatan ekonomi.

\section{SARAN}

Seluruh kalangan, tokoh agama, pemerintah, dan khususnya generasi milenial sebaiknya selalu antusias dan turut berpartisipasi dalam acara tradisi upacara buka luwur dengan baik dan tetap nguri-uri atau melestarikan tradisi tersebut. Adapun upaya lain yang bisa dilakukan generasi milenial untuk ikut melestarikan tradisi Grebeg Besar adalah menggencarkan atau mengunggah halhal terkait dengan tradisi tersebut melalui media sosial masing-masing.

\section{DAFTAR PUSTAKA}

Adibah, Ida Zahara. "Penyelidikan Sejarah Tentang Masyarakat Dan Budaya." Jurnal Madaniyah 9, no. 1 (2019): 143-62.

Effendy, Iwan. “Dinamika Grebeg Besar Demak ( Tinjauan Sejarah Dan Tradisi ).” Journal of Indonesian History 3, no. 1 (2014): 19-26.

Illaihi, Wahyu. “Komunikasi Dakwah.” Remaja Rosdakarya, 2010, 122.

Istivani Elvia Rini. "Makna Tradisi Grebeg Suro Dalam Melestarikan Budaya Bangsa Bagi Masyarakat (Studi Kasus Masyarakat Kelurahan Baluwarti Kecamatan Pasar Kliwon Surakarta)." Universitas Sebelas Maret. Universitas Sebelas Maret Surakarta, 2012. https://digilib.uns.ac.id/dokumen/detail/25392.

Rahaningmas, Saleha Astri, Sri Wahyuni, and Muh Mahendra. "Penggunaan Bahasa Indonesia Di Kalangan Generasi Milenial," 2019. https://doi.org/10.31227/osf.io/r6wku.

Sugiyono. Metode Penelitian Kuantitatif, Kualitatif, Dan R\&D. Bandung: Penerbit Alfabeta, 2013: 245-247.

Syarifah, Ani Aliatus. "Peran Masjid Agung Demak Terhadap Tradisi Grebeg Besar Di Daerah Demak" 151, no. 2 (2018): 10-17.

Taufik, Indra. "Persepsi Masyarakat Terhadap Pemulung Di Pemukiman TPA Kelurahan Bukit Pinang Kecamatan Samarinda Ulu.” Journal Sosiologi 1, no. 4 (2015): 85-95.

Dinas Pariwisata Kabupaten Demak. "Tradisi Grebeg Besar," 2019. http://pariwisata.demakkab.go.id/?p=964 .

Wamafma, Dance. “Survey Terhadap Budaya Jepang Pada.” Penelitian mandiri. Bandung, 2012. http://repository.maranatha.edu/3235/1/Budaya dalam Bisnis Jepang.pdf.

Al Qalam: Jurnal Ilmiah Keagamaan dan Kemasyarakatan Vol. 16, No. 1

Januari - Juni 2022 
Eka Erni N., dkk: Persepsi Generasi Milenial Terhadap Tradisi Grebeg Besar di Kabupaten Demak

Wijaya, Halleludin dan Hengki. Analisis Data Kualitatif: Sebuah Tinjauan Teori \& Praktik. Makassar: Sekolah Tinggi Theologia Jaffray, 2019: 135-136.

Al Qalam: Jurnal Ilmiah Keagamaan dan Kemasyarakatan Vol. 16, No. 1 Januari - Juni 2022 